\author{
KATARZYNA GROTT \\ ORCID: 0000-0002-5569-0817 \\ Uniwersytet Wrocławski \\ Katedra Kryminologii i Nauk o Bezpieczeństwie
}

\title{
PRZESTĘPSTWO - POMIĘDZY RACJONALNOŚCIĄ A EMOCJONALNOŚCIĄ
}

\begin{abstract}
Abstrakt: Czy przestępstwo może być wynikiem racjonalnej decyzji? Czy sprawca zawsze kalkuluje zyski i straty z działalności przestępczej? Próba odpowiedzi na te pytania stała się przedmiotem analizy. Celem artykułu jest więc omówienie problematyki związanej z wyborami dokonywanymi przez ludzi i świadomością ich następstw. W szczególności analizie zostały poddane założenia ekonomicznych teorii kryminologicznych i teorii racjonalnego wyboru, ujmujących sprawcę jako istotę, która w sposób racjonalny i ekonomiczny wybiera karierę przestępczą. Podstawowe zagadnienie, jakie przyświeca podjętym tu rozważaniom, odnosi się do ludzkiej emocjonalności i świadomości dokonywanych wyborów, również dotyczących zachowań przestępczych. Całość rozważań osadzona została $\mathrm{w}$ ramach teoretycznych tak zwanej analizy krytycznej wymienionych teorii i skonfrontowania ich głównych założeń z fundamentalnymi potrzebami ludzkiej egzystencji.
\end{abstract}

Słowa kluczowe: kryminologia, racjonalność, ekonomiczność zachowań przestępczych

„Racjonalny” to oparty na nowoczesnych, naukowych metodach, dobrze zaplanowany i dający zadowalające wyniki, bazujący na logicznym rozumowaniu, kierujący się rozumem, logiką ${ }^{1}$. Określenie „racjonalny” często bywa odnoszone do ludzkiego postępowania. Ponieważ kryminologia to nauka społeczna zajmująca się badaniem i gromadzeniem całościowej wiedzy na temat przestępstwa jako pewnej szczególnej formy zachowania, również w jej obrębie pojawiły się teorie traktujące zachowania przestępcze jako wynik racjonalnej decyzji jednostki.

W latach dziewięćdziesiątych XX wieku ukształtowała się ekonomiczna teoria przestępczości, będąca zastosowaniem teoretycznego dorobku ekonomii na płaszczyźnie kryminologicznej. W ekonomicznych analizach zachowań przestępczych przyjmowane jest założenie, że przestępcy działają w sposób racjonalny. Według modelu ekonomicznego jednostkę racjonalną charakteryzuje umiejętność automatycznej aktualizacji wyobrażeń o prawdopodobieństwie wraz z napływem

${ }^{1}$ https://sjp.pwn.pl/szukaj/racjonalno\%C5\%9B\%C4\%87.html (dostęp: 11.03.2019). 
wszelkich nowych informacji oraz zachowanie zgodne z założeniami teorii oczekiwanej użyteczności². Gary Becker stwierdził natomiast, że ludzie są jednostkami racjonalnymi, a ponadto w sposób racjonalny maksymalizującymi przyjemność i zadowolenie. Aparatura pojęciowa ekonomii może być zatem — zdaniem badacza - wykorzystywana do analizy wszelkich innych zachowań, które należy traktować jak zachowania rynkowe w kategoriach wyboru w warunkach ograniczonych zasobów ${ }^{3}$. Ujęcie sprawcy jako racjonalnego prowadzi do stwierdzenia, że reaguje on w sposób przewidywalny na określone bodźce zewnętrzne w postaci nagród i kar, choć nie oznacza to, że za każdym razem u potencjalnego sprawcy przed popełnieniem przestępstwa ma miejsce świadoma analiza i „ważenie” ewentualnych „za i przeciw” czy spodziewanych kosztów i zysków. Według Beckera jednostka dopuści się przestępstwa, gdy oczekiwana przez nią użyteczność z popełnienia przestępstwa ${ }^{4}$ jest większa od użyteczności, jaką mogłaby osiągnąć, gdyby czas przeznaczony na działalność przestępczą poświęciła na inne rodzaje aktywności. Decyzja o popełnieniu przestępstwa jest dodatkowo decyzją podejmowaną w warunkach ryzyka, która charakteryzuje się tym, że skutki rozpatrywanych działań są niepewne, jednakże można oszacować prawdopodobieństwo, z jakimi niepewne skutki (zyski lub straty) wystąpią5.

Becker zaproponował formalny model podejmowania decyzji przestępczych, opierając się na teorii oczekiwanej użyteczności, natomiast Pablo Fajnzylber, Daniel Lederman i Norman Loayza w swoim modelu przestępczości uwzględnili dodatkowo występowanie tak zwanych wartości moralnych potencjalnego sprawcy, przyjmując, że potencjalny sprawca dopuści się przestępstwa, gdy oczekiwany zysk netto z popełnienia przestępstwa będzie większy niż pewna wartość $m^{6}$. Z kolei Isaac Ehrlich przedstawił jednookresowy model decyzyjny, w którym na początku okresu potencjalny sprawca podejmuje decyzję, jaką część czasu przeznaczyć na działalność legalną, a jaką na działalność nielegalną, tak aby oczekiwana użyteczność z podjętej działalności była maksymalna ${ }^{7}$. Ehrlich przyjął w proponowanym modelu założenie, że działalność legalna przyniesie pewny zysk, działalność nielegalna zaś obarczona jest ryzykiem schwytania, osądzenia i zapłacenia kary za popełnione przestępstwo. Również przy zachowaniach recydywistów

2 M. Czerwonka, B. Gorlewski, Finanse behawioralne. Zachowania inwestorów i rynku, Warszawa 2008, s. 12.

${ }^{3}$ G.S. Becker, Zbrodnia i kara. Podejście ekonomiczne, [w:] idem, Ekonomiczna teoria zachowań ludzkich, Warszawa 1990, s. 80-159.

4 Oczekiwana użyteczność z popełnienia przestępstwa przez taką jednostkę została zapisana przez tego autora jako wzór - G.S. Becker, Crime and punishment: An economic approach, „Journal of Political Economy” 73, 1968, nr 2, s. 176-177.

5 T. Tyszka, Decyzje. Perspektywa psychologiczna i ekonomiczna, Warszawa 2010, s. 26.

6 Zob. P. Fajnzylber, D. Lederman, N. Loayza, What causes violent crime?, „European Economic Review" 46, 2002, nr 7, s. 1323-1357.

${ }^{7}$ I. Ehrlich, Participation in illegitimate activities: A theoretical and empirical investigation, „The Journal of Political Economy” 81, 1973, nr 3, s. 521-565. 
— uważanych powszechnie za nieracjonalne — sam fakt schwytania i ukarania, czyli poniesienia negatywnych konsekwencji przestępczej działalności, nie musi mieć większego wpływu na decyzję o kontynuowaniu takiej działalności. Ponieważ każdy człowiek kieruje się racjonalnym wyborem, także recydywista (który nie jest dotknięty wadami psychicznymi) dokonuje racjonalnego i przemyślanego wyboru. Nie tylko w przestępczej działalności ponoszone jest wysokie ryzyko zawodowe. Jest to zatem kalkulacja — zysk musi przewyższać powstałe straty8 ${ }^{8}$.

Zgodnie z tezami podejścia ekonomicznego popełniania przestępstw można oczekiwać, gdy sposobności dostępne jednostce nie ulegną zmianie. Ponieważ wszyscy ludzie - zarówno przestępcy, jak i osoby przestępcami niebędące — reagują na określone bodźce w taki sam, racjonalny sposób, zmiana kosztów i zysków z wielkim prawdopodobieństwem prowadzi do zmiany dokonywanego wyboru. W ten sposób zachowanie przestępcze, w tym przestępczość wielokrotną, należy traktować jako wybór podyktowany istniejącymi sposobnościami. Przy czym nie musi to oznaczać, że wybory są wynikiem świadomej kalkulacji. Chodzi o to, że zasada maksymalizacji przyjemności i zadowolenia traktowana jest jako najlepszy — z obiektywnego punktu widzenia — sposób wyjaśniania prawidłowości rządzących podejmowaniem wyborów.

Twórcy teorii ekonomicznych wychodzą również z założenia, że wszyscy ludzie są w pewnych warunkach w równym stopniu zdolni i skłonni do popełnienia przestępstwa. Istnieją zatem dane i niezmienne czynniki o charakterze psychicznym i społecznym, które mogą wpływać na zachowania przestępcze. Na tej podstawie zbudowano - za pomocą aparatury matematycznej - model wyboru między działalnością legalną a nielegalną, poprzez który próbuje się określić warunki, jakie muszą zostać spełnione, aby doszło do wyboru zachowania sprzecznego z prawem. Za podstawowe bodźce, które mogą w tym zakresie odegrać istotną rolę, uznano prawdopodobieństwo otrzymania kary i jej surowość (świadomość jej surowości). Bodźce te mają odstraszać przed wyborem zachowania przestępczego.

Z tego zwięzłego przedstawienia głównych założeń ekonomicznych teorii przestępczości wynika, że człowiek to istota racjonalna. Pojawia się jednak pytanie: czy człowiek to nie istota przede wszystkim emocjonalna? I czy założenie, że zachowania naruszające prawo, przez co niosące pewien ładunek napięcia, są „racjonalne”, nie jest zbytnim uproszczeniem? W literaturze zwrócono już na te wątpliwości uwagę, wskazując, że w odniesieniu do sprawców przestępstw określonego rodzaju racjonalność może być dyskusyjna. Anna Kiersztyn podnosi problem objaśniania na podstawie teorii ekonomicznych przestępstw z użyciem przemocy ${ }^{9}$, Maria Szczepaniec zaś — zachowań niezgodnych z prawem, które

8 Cyt. za: B. Szamota, Teoria ekonomiczna przestępczości (analiza krytyczna modelu wyboru zachowania przestęnego), „Państwo i Prawo” 1992, nr 1, s. 37-48.

9 Zob. A. Kiersztyn, Czy bieda czyni złodzieja? Związki między bezrobociem, ubóstwem a przestępczościa, Warszawa 2008. 
zostały popełnione nieumyślnie lub w sposób nieświadomy. Zdaniem tej ostatniej autorki takie przestępstwa nie mogą być wyjaśniane w kategoriach zachowań podejmowanych w warunkach racjonalnego wyboru, gdyż popełniając czyn w sposób nieświadomy, sprawca nie dokonuje żadnego wyboru i nie uświadamia sobie, że zachowuje się nieracjonalnie ${ }^{10}$. Sam zresztą Becker nie precyzuje, do jakiej kategorii przestępstw odnosi się jego teoria.

Teorie ekonomiczne zakładają, że zachowanie potencjalnego przestępcy jest zgodne z założeniami teorii oczekiwanej użyteczności. Co zatem oznacza owa „użyteczność”? „Użyteczność” to cecha tego, co jest użyteczne ${ }^{11}$, „użyteczny” zaś to przynoszący pożytek, potrzebny do czegoś, pomagający komuś w czymśn ${ }^{12}$. Racjonalna jednostka ma więc wybrać — zgodnie z teorią oczekiwanej użyteczności — alternatywę, której oczekiwana użyteczność będzie największa. Alternatywa oznacza wybór między jedną a drugą opcją. Przed jaką alternatywą stoi jednak sprawca przestępstwa? Między jakimi dwoma alternatywami dokonuje wyboru? Zgodnie z twierdzeniem Beckera ludzie w sposób racjonalny maksymalizują przyjemność i zadowolenie. Ale przyjemność i zadowolenie to czysto emocjonalne stany, wywołane różnymi czynnikami, a ponadto mogące mieć chwilowy charakter. Czy wybór drogi przestępczej nie prowadzi w istocie do ograniczenia przyjemności i zadowolenia? I jeśli jednostka ogranicza się tylko do chwilowego zadowolenia kosztem własnego życia, to czy w ogóle można mówić o racjonalnym wyborze? Już samo postawienie siebie w sytuacji wyboru pomiędzy alternatywą popełnienia przestępstwa a wolnością i własnym życiem może się wydawać irracjonalne. Czy dokonywanie wyboru na rzecz przestępstwa nie jest jeszcze bardziej irracjonalne, czy nie stanowi w istocie autodestrukcji?

Autodestrukcja nie jest działaniem racjonalnym — zawsze będzie wynikać z zaburzenia funkcjonowania jednostki. Każdy człowiek ma ustaloną hierarchię wartości i potrzeb, którymi kieruje się w życiu. Hierarchia ta może jednak przybierać różną postać w zależności od mechanizmów ją kształtujących. Z jednej strony mamy do czynienia z doświadczeniami jednostki (zarówno tymi z wczesnego okresu dzieciństwa i dorastania, jak i przebiegającymi aktualnie), a z drugiej — jej świadomością wolności wyboru.

Wybór drogi przestępczej jest pewnego rodzaju wyuczonym dezadaptacyjnym nawykiem, który w nurcie psychologii poznawczo-behawioralnej ${ }^{13}$ używany

10 M. Szczepaniec, Teoria ekonomiczna w prawie karnym, Warszawa 2012, s. 55.

${ }^{11}$ https://sjp.pwn.pl/szukaj/u\%C5\%BCyteczno\%C5\%9B\%C4\%87.html (dostęp: 10.03.2019).

12 https://sjp.pwn.pl/szukaj/u\%C5\%BCyteczny.html (dostęp: 10.03.2019).

13 U podłoża tego nurtu leżą ogólne tezy o naturze człowieka, genezie i mechanizmach uczenia się przystosowawczych (adaptacyjnych) i nieprzystosowawczych (dezadaptacyjnych) wzorców zachowania. Nurt ten ukształtował się w latach sześćdziesiątych XX wieku, gdy przedmiotem badań w behawioryzmie stała się samokontrola (rozumiana jako proces psychiczny) i ukryte warunkowanie, a w psychologii poznawczej znalazły zastosowanie niektóre prawa uczenia się, zwłaszcza związane z „zarządzaniem myślą”. Na początku lat sześćdziesiątych Albert Ellis, prekursor terapii poznawczej, stwierdził, że źródłem kar i nagród są nie tylko bodźce pochodzące ze środowiska ze- 
jest dla określenia powtarzającego się wzorca zachowania u jednostki. Nawyki te powstają w procesie uczenia się, a o ich poziomie nieprzystosowania świadczą: (1) sztywność reakcji, to jest uporczywe powtarzanie przez jednostkę tych samych zachowań będących odpowiedzią na niektóre tylko bodźce w sytuacji, z pominięciem innych, które są źródłem potencjalnych wzmocnień; (2) autodestrukcyjność zachowań, czyli powtarzanie reakcji będących źródłem cierpienia; (3) niedopasowanie do wymagań społecznych, to jest niezgodność z normami społecznymi czy kulturowymi środowiska, w którym jednostka żyje ${ }^{14}$. Efekty procesu uczenia się mogą zostać zniwelowane przez samą jednostkę. Zachowania autodestrukcyjne (w tym działalność przestępcza) są pozostałością po doznawanej kiedyś krzywdzie. Uświadomienie jej sobie umożliwia zrozumienie, że jednostka działa według warunkowanych schematów.

Burrhus Skinner stwierdził, że ważną rolę w powstawaniu nawyków odgrywa zjawisko warunkowania instrumentalnego, zwane też sprawczym, które opiera się na sformułowanym przez Edwarda Thorndike'a prawie efektu ${ }^{15}$. Prawo to głosi, że zachowania wywołujące odczucia pozytywne zwiększają prawdopodobieństwo pojawienia się tego typu reakcji w podobnych sytuacjach. Natomiast gdy zachowanie budzi poczucie dyskomfortu, prawdopodobieństwo jego pojawienia się w przyszłości spada. Warunkowanie sprawcze wyjaśnia sposób uczenia się przez jednostkę adaptacyjnych i dezadaptacyjnych zachowań w powiązaniu z ich efektami. Konsekwencje ujawnienia jakiegoś zachowania lub powstrzymania się od niego mogą być atrakcyjne (nazywa się je nagrodami) lub awersyjne (te nazywa się karami).

Doświadczanie pozytywnych i negatywnych konsekwencji określonych działań leży u podłoża wielu utrwalonych wzorców zachowań, w tym przestępczych. Jeśli na przykład jedynie agresja dziecka wywołuje wzrost zainteresowania ze strony rodziców, łatwo sobie wyobrazić, że będzie ono reagowało właśnie w ten sposób, gdy poczuje niedosyt ich uwagi i zaangażowania ${ }^{16}$. Podobnie rodzą się tendencje do powtarzania i utrwalania zachowań autodestrukcyjnych występujących u osób, które dzięki tym zachowaniom eliminują aktualnie działające bodźce awersyjne lub zapobiegają ich pojawieniu się. Czy zatem wybór zachowań przestępczych nie jest raczej wynikiem chęci uniknięcia przykrych emocjonalnych doznań niż racjonalnego kalkulowania zysków i strat?

wnętrznego, lecz także mogą nimi być myśli człowieka - U. Jakubowska, Podejście behawioralno-poznawcze, [w:] Psychoterapia. Szkoły, zjawiska, techniki i specyficzne problem, red. L. Grzesiuk, Warszawa 1994, s. 32-49.

14 J. Wolpe, The systematic desensitization treatment in neuroses, „Journal of Nervous and Mental Disorders" 132, 1961, s. 189-201; zob. I. Obuchowska, Dynamika nerwic. Psychologiczne aspekty zaburzeń nerwicowych u dzieci i młodzieży, Warszawa 1983; G. Corey, Teoria i praktyka poradnictwa i psychoterapii, Poznań 2005.

15 Zob. B.F. Skinner, Zachowanie się organizmów, Warszawa 1995.

16 L. Cierpiałkowska, Psychopatologia, Warszawa 2015, s. 80. 
Doświadczane przez jednostkę negatywne i pozytywne emocje biorą swój początek przede wszystkim z przekonań i z tego, jak jednostka postrzega, ocenia czy interpretuje zdarzenia życiowe ${ }^{17}$. Co istotne, przy postrzeganiu, ocenie i interpretacji tego, co dzieje się w życiu, jednostka ma wrodzoną predyspozycję do działań samozachowawczych, samorozwoju, realizacji swojego potencjału, kochania innych i siebie. Jeśli jednak jednostka, godząc się z możliwością utraty wolności czy nawet życia, popełnia przestępstwo tylko po to, aby zmaksymalizować przyjemność i zadowolenie z pozyskania większych pieniędzy, zabicia, skrzywdzenia drugiego człowieka czy oszukania kogoś, to nie racjonalna decyzja warunkuje przestępstwo, ale przekonanie o bezwartościowości własnego życia taka jednostka przejawia bowiem skłonność do samozagłady.

Skłonność do unikania sytuacji umożliwiających aktualizację potencjału rozwojowego, tworzenia i podtrzymywania przesądów i stereotypów oraz obwiniania przez jednostkę siebie i innych rodzą się, z jednej strony, w wyniku relacji z innymi znaczącymi ludźmi w dzieciństwie, ale z drugiej — tworzy ją sama jednostka w obliczu różnych w ydarzeń w późniejszym życiu. Skłonność ta powinna ulegać ciągłej zmianie, aktualizacji w miarę, jak jednostka wzrasta. Jeżeli do tej aktualizacji nie dochodzi, mamy podłoże do zachowań dezadaptacyjnych. Przestępczość jest zatem wynikiem unikania przez jednostkę okoliczności zmuszających ją do aktualizacji potencjału rozwojowego i nieracjonalnych przekonań. Ludzie tworzą takie dogmaty, jak: „muszę”, ,powinienem”, „nie ma innej możliwości”, „należy”, pomijając przy tym samych siebie, swoje potrzeby, lecz nie jako mordercy, złodzieja czy oszusta, ale jako człowieka. Te autodestrukcyjne aksjomaty podlegają internalizacji, w wyniku czego zaczyna się proces autosugestii i autoindoktrynacji. Proces ten musi jednak prowadzić — u świadomej jednostki — do uaktywnienia się wielu negatywnych emocji: smutku, żalu czy poczucia krzywdy, a w konsekwencji do przemyśleń, aby je zniwelować. U tych, którzy działają schematycznie bez jakiejkolwiek refleksji, emocje te w ogóle mogą się nie pojawić. Konsekwencją procesu internalizowania i podtrzymywania autodestrukcyjnych przekonań będzie przestępczość. Zdolność do racjonalnego myślenia może wynikać tylko z tendencji samozachowawczych i aktualizowania indywidualnego potencjału rozwojowego jednostki.

W jaki sposób może zatem dojść do „racjonalnego” wyboru zachowań przestępczych? Teorie racjonalnego wyboru (rational choice theory) zakładają, że decyzja o popełnieniu przestępstwa jest podejmowana w warunkach ryzyka, które charakteryzują się tym, że skutki rozpatrywanych działań są niepewne. Naruszenie prawa jest więc postrzegane jako ryzykowne podejście w grze, w której można wygrać albo stracić. Kto straci, musi zapłacić cenę. Jeżeli ceną jest własne życie,

17 Jest to podstawowe założenie racjonalno-emotywnej terapii zachowania (rational emotive behavior therapy - REBT), stworzonej przez Alberta Ellisa. Centralnym pojęciem teorii i praktyki klinicznej jest $\mathrm{ABC}$ - koncepcja osobowości Ellisa — idem, The revised ABC's of rational-emotive therapy, „Journal of Rational-Emotive and Cognitive-Behavior Therapy” 9, 1991, s. 139-172. 
ryzyko jest wysokie. Ale czy jednostka rozważa w ogóle popełnienie przestępstwa w tych kategoriach? Z teorii ekonomicznych wynika, że raczej nie sięga aż tak głęboko. A zatem czy przestępczość nie jest wynikiem refleksji warunkowanej emocjami? Czy zysk w postaci zaspokojenia własnych, egoistycznych, emocjonalnych doznań i potrzeb może przeważyć nad alternatywą utraty wolności czy życia? W teoriach racjonalnego wyboru pomija się — zdaniem autorki niniejszego tekstu - jeden istotny element kalkulacji, a mianowicie rozważania o człowieku i jego życiu. Czy sprawca przestępstwa przy analizie oraz dokonywaniu racjonalnego i przemyślanego wyboru, kalkulacji „zysk musi przewyższać powstałe straty" bierze pod uwagę własne życie? Czy uświadamia sobie, że w wyniku własnych działań może ponieść największy z możliwych kosztów — stracić życie? Jesteśmy istotami, które mają wrodzony instynkt samozachowawczy, lecz także istotami żyjącymi wśród innych. Wszelkie działania powinny więc - jak się zdaje — być podporządkowane zachowaniu nie tylko własnego, ale i cudzego życia. Jeśli w kalkulacjach wybierane jest czynienie zła, oznacza to, że jednostka ma w sposób niewłaściwy ukształtowany obraz życia, a co za tym idzie - mechanizm ochrony samego siebie przed zniszczeniem. Nie można zatem — jak wskazują teorie ekonomiczne - przewidzieć i matematycznie zmierzyć reakcji sprawcy na określone bodźce zewnętrzne. Jeżeli recydywista, pomimo poniesienia już kary, ponownie wybiera przestępstwo, znaczy to, że nie potrafi wyciągnąć ze swojego postępowania odpowiednich wniosków. Jeżeli natomiast jedyny wniosek, jaki został przez niego wyciągnięty, dotyczy sposobu popełnienia przestępstwa i tego, co zrobić, aby nie zostać schwytanym, to jego instynkt samozachowawczy nie funkcjonuje prawidłowo.

Przytoczone rozważania prowadzą do zanegowania stwierdzenia, że wszyscy ludzie - zarówno przestępcy, jak i nieprzestępcy — reagują na określone bodźce w taki sam, racjonalny sposób. Zachowania przestępczego, w tym przestępczości wielokrotnej, nie można traktować jako wyboru podyktowanego przez istniejące sposobności, ale jako wynik nieprawidłowo ukształtowanej postawy i braku świadomej kalkulacji. Traktowanie zasady maksymalizacji przyjemności i zadowolenia jako najlepszego — z obiektywnego punktu widzenia - sposobu wyjaśniania prawidłowości rządzących podejmowaniem wyborów jest efektem ograniczonego procesu myślowego potencjalnego sprawcy, pozbawionego refleksji egzystencjalnej. Tylko autodestrukcyjna jednostka może rozważać, że użyteczność osiągnięta za pomocą przestępstwa jest wyższa od użyteczności płynącej z zaangażowania się w zgodną z prawem działalność, i w konsekwencji tych rozważań popełnić przestępstwo.

Trudno również zgodzić się z twierdzeniem, że wszyscy ludzie są w pewnych warunkach $\mathrm{w}$ równym stopniu zdolni i skłonni do popełnienia przestępstwa. Nie ma dwóch takich samych sytuacji ani dwóch takich samych osób. Nie ma zatem niezmiennych czynników o charakterze psychicznym i społecznym, które mogą wpływać na zachowania przestępcze. Każda sytuacja, tak jak każdy człowiek, jest 
wyjątkowa i w swym charakterze subiektywistyczna. Nawet ten sam człowiek może zachować się inaczej w takiej samej sytuacji. Nie ma zatem możliwości, aby matematycznie określić prawdopodobieństwo zachowań przestępczych. Będą to zawsze wyniki spekulacyjne. Przestępczość jest bowiem efektem irracjonalnych, autodestrukcyjnych przekonań, wynikających ze schematów, którym człowiek „ulega".

Struktury poznawcze, zwane schematami, to podstawowe elementy funkcjonowania psychologicznego i procesów adaptacyjnych jednostki, które są odpowiedzialne za nadawanie znaczenia życiu i zachodzącym w jego trakcie zdarzeniom. Znaczenia te są zatem subiektywną interpretacją kontekstu sytuacyjnego i relacji między jednostką a tym kontekstem ${ }^{18}$. Każda kategoria znaczenia współwystępuje ze specyficznymi emocjami, świadomością, pamięcią i zachowaniem. Znaczenie aktywizuje strategie adaptacji, ponieważ zarówno na poziomie procesów działających automatycznie, jak i na poziomie przemyślanych decyzji pełni funkcje kontrolujące wobec różnych systemów psychicznych, na przykład emocji, świadomości, pamięci oraz zachowania. Konstruowane przez jednostkę znaczenia mogą być właściwe lub niewłaściwe ze względu na relację do danego kontekstu lub celu. Te niewłaściwe to poznawcze zniekształcenia, które są dysfunkcjonalne lub dezadaptacyjne z perspektywy aktywizowanych systemów, na przykład emocji. Zniekształcenia poznawcze obejmują błędy znaczenia, przetwarzania informacji lub oba błędy naraz.

Przestępczość to rezultat skonstruowanych przez jednostkę dezadaptacyjnych znaczeń zdarzeń i znaczeń odnoszących się do samego siebie, własnego życia, doświadczeń osobistych i przyszłości. Istnieją dwa wymiary znaczenia: obiektywne, powszechnie uznane, często niemające większego wpływu na jednostkę, oraz osobiste lub prywatne, które mogą mieć istotne implikacje dla zachowań. Wyróżnia się trzy poziomy procesów poznawczych: (1) poziom przedświadomy, automatyczny, nieintencjonalny; (2) poziom świadomy; (3) poziom metapoznawczy, który zawiera realistyczne i racjonalne treści ${ }^{19}$. Procesy te mogą doznawać jednak pewnych zaburzeń. Może bowiem nie dojść do poziomu świadomego i metapoznawczego. Człowiek jest — jak to obrazowo przedstawia się w filozofii humanistycznej — jak żołądź, który — jeśli tylko zaistnieją odpowiednie warunki — zaktualizuje się w postaci dębu ${ }^{20}$. Człowiek ma zatem ukształtowaną naturę, przywołując poglądy kryminologów pozytywistycznych — dobrą naturę. Za egzystencjalistami można powtórzyć, że człowiek podąża w kierunku urzeczywistnienia się ${ }^{21}$. W każdym momencie życia, ciągle na nowo, człowiek poprzez

18 Zob. B.A. Alford, A.T. Beck, Terapia poznawcza jako teoria integrujaca psychoterapie, Kraków 2005.

19 Ibidem, s. 12-14.

20 G. Corey, op. cit., s. 236.

21 Egzystencjaliści nie uznają organizmicznie zdeterminowanej wewnętrznej „,natury” człowieka. Zasada przyczynowości, przyjmowana i respektowana w psychologii humanistycznej, jest 
nadawanie życiu znaczenia i dokonywane wybory decyduje, co zrobić ze swoim istnieniem. Jako istota intencjonalna jest w stanie przekroczyć determinizm wynikający z zaprogramowanych schematów, co powoduje, że jego sensotwórcza aktywność nie podlega żadnym ograniczeniom. Człowiek zatem powinien żyć w teraźniejszości, a nie przeszłością, powinien być - jak przyjmuje fenomenologia i subiektywizm - skoncentrowany na bieżącym doświadczaniu siebie, na świadomości zdarzeń zewnętrznych i wewnętrznych, tego, co zachodzi „tu i teraz". Świadome doświadczanie i nadawanie sensu istnienia jest jedynym kryterium poznania rzeczywistości i siebie oraz najważniejszym przejawem racjonalnie podejmowanych decyzji.

Przejawem ludzkiej egzystencji jest wolność, wartość, odpowiedzialność i autonomia. Przyglądając się życiorysom przestępców, trudno - zdaniem autorki - stwierdzić, aby te walory im przyświecały. Czy człowiek, którym rządzi chęć zadawania innym cierpienia, jest naprawdę wolny? Czy życie, w którym znaczenie ma posiadanie i poniżanie drugiego człowieka, ma wartość? Czy podejmując — za wszelką cenę - próby uniknięcia kary, sprawca bierze na siebie odpowiedzialność za własne czyny? Czy o schematycznym i pozbawionym jakiejkolwiek refleksji zachowaniu człowieka można powiedzieć, że jest autonomiczne? Dokonywanie wyboru drogi przestępczej to ból, którego można uniknąć w procesie poszukiwania głębszego sensu zdarzeń i nadawania znaczenia własnemu życiu.

Człowieka oprócz potrzeb fizjologicznych, to jest najbardziej pierwotnych potrzeb, takich jak potrzeba pożywienia, wody, snu, ma również potrzeby stabilności i bezpieczeństwa (fizycznego, czyli braku bólu, cierpienia i zagrożenia życia, a także psychicznego, czyli utrzymania porządku i stabilności w środowisku, podtrzymywania układu odniesienia — mapy świata, światopogląd), dzięki któremu świat staje się zrozumiały i przewidywalny), potrzeby przynależności i miłości (człowiek pragnie tworzyć z kimś jedność i bliskość, czuć się kochany i akceptowany; potrzebuje przynależeć do rodziny, wspólnoty rówieśników czy innych grup społecznych) oraz potrzeby szacunku i pozytywnej samooceny (człowiek pragnie doświadczać siebie i być postrzegany jako osoba kompetentna i skuteczna, godna szacunku ze strony innych i samego siebie). Pojawia się również piąta grupa potrzeb, która wychodzi poza te podstawowe, często określanych jako potrzeby wyższego stopnia, to jest potrzeba samoaktualizacji — to pragnienie spełnienia gatunkowej i indywidualnej potencjalności ${ }^{22}$.

Ze wskazanymi grupami potrzeb związane są dwie podstawowe zasady motywacji człowieka do podejmowania różnych zachowań. Są to: motywacja braku, z którą mamy do czynienia, gdy nie są zaspokojone potrzeby podstawowe, i mo-

odrzucana w podejściu egzystencjalnym na rzecz zasady rozumienia i interpretacji - J.F. Burke, Contemporary Approaches to Psychotherapy \& Counseling. The Self-Regulation and Maturity, Pacific Grove 1989; P.K. Oleś, Wprowadzenie do psychologii osobowości, „Wykłady z Psychologii” 11, Warszawa 2005.

22 Zob. A.H. Maslow, W strone psychologii istnienia, Warszawa 1986. 
tywacja istnienia, gdy nie są zaspokojone potrzeby aktualizacji potencjalności. $\mathrm{O}$ ile niezaspokojenie potrzeb podstawowych prowadzi do stanu napięcia, które wymaga redukcji, jak w sytuacji głodu, braku snu czy poczucia braku szacunku, o tyle potrzeba samorealizacji jest potrzebą wzrostu, dążeniem do przekroczenia stanu bieżącego i doświadczania wartości istnienia. Poprzez dążenie ku wyższym celom człowiek może pokonać stan niezaspokojenia podstawowych potrzeb organizmu. Gdy nie są zaspokojone potrzeby podstawowe, pojawia się choroba, gdy zaś człowiek nie aktualizuje swojej potencjalności, jest nieszczęśliwy, pozbawiony sensu i radości życia ${ }^{23}$. Wtedy pojawia się autodestrukcja. Aby tak się nie stało, konieczne jest umiejscowienie przez jednostkę samej siebie, własnego życia i wszelkiego subiektywnego doświadczenia w „tu i teraz”. Potrzeba, aby jednostka objęła świadomością wszystko to, co dzieje się w danym momencie jej życia i co jest jej potencjalnie dostępne. Całość doświadczenia — jak wskazuje Carl Rogers — tworzy pole fenomenologiczne, które składa się z doświadczeń świadomych, przedstawionych $\mathrm{w}$ formie symbolicznej, oraz doświadczeń nieświadomych, niemających postaci symbolicznej24 ${ }^{24}$ Wrodzoną tendencją każdego organizmu jest tendencja do aktualizacji, czyli rozwijania wszelkich zdolności i możliwości, które służą jego podtrzymaniu i ulepszaniu. Ludzie z natury zatem zmierzają do stawania się w pełni funkcjonującą osobą, która w procesie samorozwoju staje się coraz bardziej otwarta na doświadczenia, akceptująca własne uczucia i pragnienia, zdolna do życia w danej sytuacji i momencie, spontaniczna i wolna w dokonywanych wyborach, ufna wobec siebie i ludzkiej natury, zdolna do zrównoważonej i zgodnej z rzeczywistym doświadczeniem ekspresji uczuć (w tym agresji) oraz twórcza i nonkonformistyczna. Działalność przestępcza jest zaprzeczeniem tych wszystkich wartości. Nie chodzi bowiem o to, aby w ramach samorozwoju być otwartym na doświadczanie zadawania cierpienia innym, bezwarunkowo stawiać na pierwszym miejscu własne uczucia i pragnienia, przypisywać sobie prawo do wolnych wyborów i pokładać ufność wobec własnej ,,przestępczej natury”, wyrażać w sposób nieograniczony agresję czy być nonkonformistą w każdej sytuacji. Samorozwój ma uwzględniać uczucia i pragnienia drugiego człowieka, który powinien stać się granicą ludzkich zachowań.

W kalkulacji podejmowanej przez sprawcę przestępstwa - w ujęciu teorii racjonalnego wyboru - zdaje się, nie ma miejsca na rozważania ani o samym sobie, ani o drugim człowieku, ani o konsekwencjach własnych zachowań, które mogą godzić w dobra innych ludzi. Racjonalnie myślący człowiek bierze jednak wszystkie te okoliczności pod uwagę. Gdy jednostka pomija drugiego człowieka, kieruje się wdrukowanymi emocjami, które mają wpływ na percepcję samej siebie

23 Zob. A.H. Maslow, Motywacja i osobowość, Warszawa 1990.

24 Zob. C.R. Rogers, On Becoming a Person, Boston 1961. 
(tak zwanego $\mathrm{Ja}^{25}$ ). Jeżeli nie będzie dochodziło do samoaktualizacji tej percepcji, może dojść do ukształtowania się zachowań irracjonalnych.

Osobiste cele i ideały konstytuują Ja idealne jednostki. Jak stwierdził Rogers, pewien poziom rozbieżności między obrazem Ja a Ja idealnym jest stanem naturalnym (między innymi ze względu na potrzebę uznania ze strony innych ludzi) i sprzyja angażowaniu się osoby w proces aktualizacji idealnego Ja. Wraz z procesem wyłaniania się Ja w świadomości jednostki następuje rozwój potrzeby aprobaty i uznania ze strony innych oraz potrzeby szacunku (aprobaty) dla samej siebie. Niezaspokojenie potrzeby aprobaty ze strony innych prowadzi do przyswojenia przez jednostkę „warunków własnej wartości” (warunków koniecznych do zachowania szacunku dla siebie). Konsekwencją introjekcji owych warunków jest zniekształcenie percepcji tych doświadczeń jednostki (potrzeb, uczuć czy zachowań), które są niezgodne z nimi. Zgodność vs niezgodność między rzeczywistym doświadczeniem organizmu a obrazem Ja jest uwarunkowana oddziaływaniami środowiska społecznego, a dokładnie poziomem bezwarunkowej i warunkowej akceptacji dziecka przez rodziców i inne osoby znaczące. Jeśli osobiste doświadczenia jednostki, jej obraz Ja i idealne Ja są spójne, wówczas tendencje aktualizacyjne i samoaktualizacyjne są odpowiednio realizowane i proces stawania się w pełni funkcjonującą osobą przebiega bez zakłóceń. Jeśli natomiast między doświadczeniem jednostki a jej obrazem Ja wystąpi niezgodność, wówczas tendencje aktualizacyjne mogą być niezgodne z tendencjami samoaktualizacyjnymi, co sprzyja uaktywnieniu się różnych zachowań obronnych (na przykład racjonalizacji, kompensacji, fantazjowania) i podatności (vulnerability) jednostki na zakłócenia w rozwoju. Niezgodność między rzeczywistym doświadczeniem a obrazem Ja może być przez jednostkę uświadamiana, wówczas pojawia się poczucie napięcia i zamieszania oraz próby równoczesnego osiągnięcia dwóch pozostających z sobą w konflikcie celów. Takiemu stanowi najczęściej towarzyszy poczucie mniejszej wartości, pogłębiająca się nieadekwatność w życiu codziennym i dezorganizacja, co prowadzi do różnych form nieprzystosowania społecznego jednostki. Jeśli osoba jest nieświadoma niespójności, wówczas pojawia się lęk bądź poczucie zagrożenia, którego powody — ze względu na uaktywnienie się zachowań obronnych — nie są przez nią rozpoznane. Poczucie zagrożenia wystąpi, gdy osoba antycypuje rozbieżność między rzeczywistym doświadczeniem a obrazem Ja bądź między obrazem Ja a Ja idealnym. Zachowania osoby — nieświadomej rozbieżności między Ja a rzeczywistym doświadczeniem — raz będą pod wpływem tendencji aktualizacyjnych, innym razem pod naporem fałszywego czy idealnego Ja. Taki stan prowadzi do różnych form dezorganizacji, w tym do takich zachowań nieracjonalnych jak przestępczość.

25 „Ja” to zbiór spostrzeżeń i koncepcji jednostki na temat jej zdolności i cech, relacji z innymi osobami i ze światem, wartościowania doświadczeń, obiektów i osób, osobistych celów i ideałów - C.R. Rogers, Client-Centered Therapy, Boston 1951, s. 136. 
Przenosząc powyższe na grunt etiologii kryminalnej, można stwierdzić, że gdy w dziecku nie wykształci się szacunek do samego siebie, albowiem spotkało się z dezaprobatą ze strony ważnych dla niego osób, konsekwencją będzie podejmowanie przez nie zachowań pozbawionych akceptacji jednej z najistotniejszych wartości - ludzkiego życia. Jego sens może mieć różne źródła. Może wywodzić się — jak stwierdził twórca analizy egzystencjalnej i logoterapii Viktor Frankl — z twórczej i pożytecznej pracy, doświadczania i odkrywania piękna, prawdy i miłości czy osobistej postawy, na przykład w obliczu utraty, zagrożenia i cierpienia. Ludzkie życie, podobnie jak świat, pełne jest różnych obiektywnych wartości, a podstawowym zadaniem człowieka jest odkrycie tych wartości i życie zgodnie $\mathrm{z}$ nimi ${ }^{26}$. Ludzkie życie nie ma sensu, to życie jest sensem.

Człowiek to nie tylko fizyczność, ale i duchowość. Zdrowy człowiek to taki, który żyje świadomie, przekraczając uwarunkowania biologiczne i społeczne oraz poszerzając granice samego siebie. Staje się zdolny do transcendencji (autotranscendencji), dzięki której to życie staje się sensem — uaktywnia procesy głębszego zrozumienia samego siebie, wglądu w to, „kim jest”, ,skąd pochodzi” i , „okąd zmierza", wychodzi z sercem ku innym ludziom i angażuje się w realizację ważnych idei, tworzy „nowego siebie” na podstawie wspomnień z przeszłości, lecz także ufności w przyszłość. To prowadzi do głębszego zrozumienia sensu własnego istnienia, a nawet związków między światem a nieskończonością. Autodestrukcyjny człowiek nie znajdzie niczego - będzie niszczył życie innych ludzi, a przez to i swoje własne. Przestępczość to oznaka braku swobodnego i otwartego spełniania się egzystencji człowieka. Jeżeli potencjalny sprawca będzie miał tego świadomość, będzie mógł dokonywać racjonalnych wyborów, a za taki nie można uznać wyboru zachowań przestępczych - jest on bowiem wynikiem subiektywnych wyobrażeń i przekonań.

Ten subiektywizm jest również zakorzeniony w korzyści mogącej objawiać się w postaci seksualnych odczuć wiązanych z zakazaną działalnością. Ta szczególna ekscytacja, która jest połączona z niebezpieczeństwem bycia złapanym, pobudzenie przy popełnianiu czynu zabronionego i orgiastyczny tryumf przy sukcesie, krótko mówiąc - żądza zła, zmienia optykę kryminologii szukającej uwarunkowań przestępczości w racjonalności sprawcy. Przestępczość ukazuje się wtedy jako wyraz pragnienia „wolności” i luksusu, ekscytującego sposobu życia w materialistycznym społeczeństwie i poszukiwania dreszczyku emocji. Przestępczość przestaje być tym samym wynikiem racjonalnych decyzji, ale skrzywionego obrazu czerpania przyjemności ze zła. Ukształtowanie tego obrazu zależy od różnych czynników, których w żaden sposób nie można wpisać w koncepcję racjonalnych wyborów.

26 Zob. V. Frankl, Homo patiens, Warszawa 1978; idem, Nieuświadomiony Bóg, Warszawa 1984. 


\title{
CRIME — BETWEEN RATIONALITY AND EMOTIONALITY
}

\author{
Summary
}

Can a crime be the result of a rational decision? Does the perpetrator always calculate the profits and losses from criminal activity? An attempt to answer these questions has become the subject of analysis. The aim of the article is therefore to discuss the issues related to the choices made by people and the awareness of their consequences. In particular, the assumptions of economic criminological theories and the rational choice theories, which recognise a perpetrator as a being who rationally and economically chooses a criminal career, have been analysed. The basic issue that guides the considerations here relates to human emotionality and awareness of the choices made, including those concerning criminal behaviour. All considerations were embedded in the theoretical framework of the so-called critical analysis of the above theory and confronting their main assumptions with the fundamental needs of human existence.

Keywords: criminology, rationality, economics of criminal behaviour

\section{BIBLIOGRAFIA}

Alford B.A., Beck A.T., Terapia poznawcza jako teoria integrująca psychoterapię, Kraków 2005.

Becker G.S., Crime and punishment: An economic approach, „Journal of Political Economy” 73, $1968, \mathrm{nr} 2$.

Becker G.S., Zbrodnia i kara. Podejście ekonomiczne, [w:] idem, Ekonomiczna teoria zachowań ludzkich, Warszawa 1990.

Burke J.F., Contemporary Approaches to Psychotherapy \& Counseling. The Self-Regulation and Maturity, Pacific Grove 1989.

Cierpiałkowska L., Psychopatologia, Warszawa 2015.

Corey G., Teoria i praktyka poradnictwa i psychoterapii, Poznań 2005.

Czerwonka M., Gorlewski B., Finanse behawioralne. Zachowania inwestorów i rynku, Warszawa 2008.

Ehrlich I., Participation in illegitimate activities: A theoretical and empirical investigation, „The Journal of Political Economy" 81, 1973, nr 3.

Ellis A., The revised ABC's of rational-emotive therapy, „, Journal of Rational-Emotive and CognitiveBehavior Therapy" 9, 1991.

Fajnzylber P., Lederman D., Loayza N., What causes violent crime?, „European Economic Review” 46, 2002, nr 7.

Frankl V., Homo patiens, Warszawa 1978.

Frankl V., Nieuświadomiony Bóg, Warszawa 1984.

Jakubowska U., Podejście behawioralno-poznawcze, [w:] Psychoterapia. Szkoty, zjawiska, techniki i specyficzne problem, red. L. Grzesiuk, Warszawa 1994.

Kiersztyn A., Czy bieda czyni złodzieja? Zwiąki między bezrobociem, ubóstwem a przestępczościa, Warszawa 2008.

Obuchowska I., Dynamika nerwic. Psychologiczne aspekty zaburzeń nerwicowych u dzieci i młodzieży, Warszawa 1983.

Oleś P.K., Wprowadzenie do psychologii osobowości, „Wykłady z Psychologii” 11, Warszawa 2005.

Maslow A.H., Motywacja i osobowość, Warszawa 1990.

Maslow A.H., W strone psychologii istnienia, Warszawa 1986.

Rogers C.R., Client-Centered Therapy, Boston 1951. 
Rogers C.R., On Becoming a Person, Boston 1961.

Skinner B.F., Zachowanie się organizmów, Warszawa 1995.

Szamota B., Teoria ekonomiczna przestępczości (analiza krytyczna modelu wyboru zachowania przestepnego), „Państwo i Prawo” 1992, nr 1.

Szczepaniec M., Teoria ekonomiczna w prawie karnym, Warszawa 2012.

Tyszka T., Decyzje. Perspektywa psychologiczna i ekonomiczna, Warszawa 2010.

Wolpe J., The systematic desensitization treatment in neuroses, „Journal of Nervous and Mental Disorders" 132, 1961. 